\title{
Efek Belanja Modal Pemerintah Terhadap Indeks Pembangunan Manusia di Kabupaten/Kota Provinsi Sulawesi Selatan Jurnal Ecces
}

\author{
Wardihan Sabar \\ ${ }^{1}$ Program Studi Ilmu Ekonomi \\ Fakultas Ekonomi dan Bisnis Islam Universitas Islam Negeri Alauddin Makassar \\ Jl. Yasin Limpo, No. 36 Samata, Gowa, Sulawesi Selatan \\ E-mail : wardihan.sabar@uin-alauddin.ac.id
}

\section{Abstrak: Efek Belanja Modal Pemerintah Terhadap Indeks Pembangunan Manusia Di Kabupaten/Kota Provinsi Sulawesi Selatan}

Capaian IPM Provinsi Sulawesi Selatan selama kurun waktu 2007-2016 terus mengalami peningkatan, namun angkanya masih lebih rendah dibandingkan angka IPM Nasional. Artikel ini mengulas pengaruh belanja belanja modal pendidikan, belanja modal kesehatan, belanja modal ekonomi terhadap indeks pembangunan manusia di Kabupaten/Kota Provinsi Sulawesi Selatan periode 2007-2016. Penelitian ini merupakan penelitian kuantitatif dengan pendekatan eksplanatori. Jenis data yang digunakan pada penelitian ini berupa data sekunder dalam bentuk data panel (pooled data) di Kabupaten/Kota Provinsi Sulawesi Selatan. Variabel yang digunakan pada penelitian ini adalah belanja modal pendidikan, belanja modal kesehatan dan belanja modal ekonomi dari APBD seluruh Kabupaten/Kota Provinsi Sulawesi Selatan. Estimasi parameter dari variabel tersebut dengan menggunakan metode Ordinary Least Square (OLS). Hasil penelitian ini menunjukkan bahwa belanja modal pendidikan, dan belanja modal kesehatan, dan belanja modal ekonomi berpengaruh signifikan terhadap IPM di Provinsi Sulawesi Selatan. Peningkatan alokasi belanja modal pada ketiga sektor ini memberikan dampak positif terhadap upaya meningkatkan indeks pembangunan manusia di Kabupaten/Kota Provinsi Sulawesi Selatan.

Kata kunci: Indeks Pembangunan Manusia, Sulawesi Selatan, Belanja Pemerintah.

\section{Abstract : The Effect of Government Capital Spending On Human Development Index in the Regency / City of South Sulawesi Province}

The achievements of the HDI of South Sulawesi Province during the 2007-2016 period continued to increase, but the figure was still lower than the National HDI. This article reviews the effects of education capital spending, health capital spending, economic capital spending on the human development index in the Regency / City of South Sulawesi Province 
in the 2007-2016 period. This research is a quantitative study with the approach used is an explanatory. The type of data used in this study is secondary data in the form of pooled data in the Regency / City of South Sulawesi Province. The variables used in this study are education capital spending, health capital spending and economic capital spending from the APBD throughout the Regency / City of South Sulawesi Province. Estimated parameters of these variables using the Ordinary Least Square (OLS) method. The results of this study indicate that education capital spending, and health capital spending, and economic capital spending have a significant effect on HDI in South Sulawesi Province. Increased capital spending allocations in these three sectors have a positive impact on efforts to improve the human development index in the Regency / City of South Sulawesi Province.

Keywords: Human Development Index, South Sulawesi, Government Capital Spending.

\section{PENDAHULUAN / INTRODUCTION}

Manusia adalah kekayaan bangsa yang sesungguhnya. Tujuan utama dari pembangunan adalah menciptakan lingkungan yang memungkinkan bagi rakyatnya untuk menikmati umur panjang, sehat, dan menjalankan kehidupan yang produktif. Hal ini tampaknya merupakan suatu kenyataan yang sederhana. Tetapi hal ini seringkali terlupakan oleh berbagai kesibukan jangka pendek untuk mengumpulkan harta dan uang. (Human Development Report 1990).

Luasnya cakupan pembangunan manusia menjadikan peningkatan IPM sebagai manifestasi dari pembangunan manusia dapat ditafsirkan sebagai keberhasilan dalam meningkatkan kemampuan dalam memperluas pilihan-pilihan (enlarging the choices of the people). Seperti diketahui, beberapa faktor penting dalam pembangunan yang sangat efektif bagi pembangunan manusia adalah pendidikan dan kesehatan. Dua faktor penting ini merupakan kebutuhan dasar manusia yang perlu dimiliki agar mampu meningkatkan potensinya.

Konsep pembangunan manusia memang terdengar berbeda dibanding konsep klasik pembangunan yang memberikan perhatian utama pada pertumbuhan ekonomi. Pembangunan manusia menekankan pada perluasan pilihan masyarakat untuk hidup penuh dengan kebebasan dan bermartabat. Tidak hanya itu, pembangunan manusia juga berbicara tentang perluasan kapabilitas individu dan komunitas untuk memperluas jangkauan pilihan mereka dalam upaya memenuhi aspirasinya.

Perspektif pembangunan manusia merupakan sebuah pemikiran radikal dalam konsep pembangunan. Perspektif ini menggantikan konsep pertumbuhan ekonomi dan pertumbuhan pendapatan per kapita yang digunakan oleh perencana kebijakan sebelumnya. 
Pertumbuhan ekonomi yang dipandang dari sisi perdagangan, investasi, dan teknologi merupakan hal yang esensial. Akan tetapi, hal itu hanya melihat manusia sebagai alat untuk mencapai pertumbuhan, dan bukan sebagai tujuan dari pembangunan. Pembangunan manusia memperluas pembahasan tentang konsep pembangunan dari diskusi tentang caracara (pertumbuhan produk domestik bruto/PDB), ke diskusi tentang tujuan akhir dari pembangunan. Pembangunan manusia juga merupakan perwujudan jangka panjang, yang meletakkan pembangunan di sekeliling manusia, dan bukan manusia di sekeliling pembangunan (BPS, 2014).

Umumnya, semakin tinggi kapabilitas dasar yang dimiliki suatu bangsa, semakin tinggi pula peluang untuk meningkatkan potensi bangsa itu. Di tengah eskalasi persaingan global, tuntutan terhadap kapabilitas dasar itu dirasakan semakin tinggi. Jika tidak demikian maka bangsa tersebut akan kalah bersaing dengan bangsa-bangsa lain yang lebih maju. Untuk meningkatkan IPM semata-mata tidak hanya pada pertumbuhan ekonomi karena pertumbuhan ekonomi baru merupakan syarat perlu. Agar pertumbuhan ekonomi sejalan dengan pembangunan manusia, maka pertumbuhan ekonomi harus disertai dengan syarat cukup yaitu pemerataan pembangunan. Dengan pemerataan pembangunan terdapat jaminan bahwa semua penduduk dapat menikmati hasil-hasil pembangunan.

Di Indonesia bagian timur, Provinsi Sulawesi Selatan disorot sebagai salah satu provinsi dengan perkembangan pembangunan yang cukup pesat. Dana Anggaran Belanja Pembangunan pada APBD Provinsi Sulawesi Selatan mengalami peningkatan setiap tahunnya. Sektor-sektor penunjang pembangunan manusia seperti sektor pendidikan, kesehatan, dan ekonomi juga turut mengalami peningkatan anggaran. Data publikasi BPS memperlihatkan bahwa IPM Sulawesi Selatan telah mengalami peningkatan dalam beberapa tahun terakhir.

Tahun 2007 IPM Provinsi Sulawesi Selatan sebesar 69,62 persen dan terus mengalami peningkatan sampai pada tahun 2016 mencapai angka 73,89 persen. Jika dilihat berdasarkan pencapaian IPM Provinsi Sulawesi Selatan, selama kurun waktu 2007-2016 ini menggambarkan IPM Provinsi Sulawesi Selatan terus mengalami peningkatan namun angkanya masih relatif lebih rendah dibandingkan angka IPM Nasional.

Sektor pendukung dimensi IPM yang terkandung dalam anggaran belanja pembangunan seperti sektor pendidikan, kesehatan, dan ekonomi tentunya juga memegang peranan. Kebutuhan yang berbeda pada tiap daerah kabupaten/kota juga membuat 
perbedaan pengalokasian anggaran dan tentunya juga berimbas pada pencapaian IPM. Walaupun angka IPM tersebut mengalami peningkatan, namun pencapaian tersebut masih jauh dan belum mampu mencapai hasil yang diharapkan.

Belanja pemerintah diprioritaskan untuk melindungi, dan meningkatkan kualitas kehidupan masyarakat dalam upaya memenuhi kewajiban daerah yang diwujudkan dalam bentuk peningkatan pelayanan dasar, pendidikan, penyediaan fasilitas pelayanan kesehatan, fasilitas sosial dan fasilitas umum yang layak serta mengembangkan jaminan sosial dengan mempertimbangkan analisis standar belanja, standar harga, tolak ukur kinerja dan standar pelayanan minimal yang ditetapkan dalam peraturan perundang-undangan (UU Nomor 32 Tahun 2004).

Beberapa penelitian terdahulu yang terkait penelitian yang dilakukan diantaranya oleh Arifin (2014) dalam jurnal yang berjudul "Pengaruh Belanja Pemerintah Sektor Kesehatan, Belanja Pemerintah Sektor pendidikan dan Pertumbuhan Ekonomi terhadap IPM di Jawa Timur 2006-2013". Irawan (2014) "Analisis Faktor-faktor yang mempengaruhi IPM di Indonesia". Paddu dkk (2014), dalam jurnal dengan judul Pengaruh Belanja Pemerintah Sektor pendidikan dan Sektor Kesehatan terhadap IPM dan Pertumbuhan Ekonomi Kabupaten Sinjai. Abdul Kadir, dkk, (2017). "Pengaruh Pengeluaran Kesehatan dan Pendidikan Serta Infrastruktur terhadap Indeks Pembangunan Manusia di Provinsi Maluku". Sofilda, et al Z. (2015). Government Spending Contributions on per Capita Income and its Effect toward the Human Development Index (Comparative Study between Western Indonesia and Central \& East Indonesia". Edeme, (2014). Analyzing the effects of sectoral public spending on human development in nigeria: evidence from panel data".

Kesamaan dalam penelitian ini terletak pada objek penelitian menyangkut indeks pembangunan manusia, dengan salah satu faktor penentu Belanja modal pemerintah sektor publik diantaranya belanja modal pendidikan, kesehatan dan ekonomi. Sementara perbedaan dalam penelitian ini, terletak pada wilayah pengamatan mencakup Kabupaten/Kota di Provinsi Sulawesi Selatan dengan penggunaan data panel. Terdapat pula perbedaan dari sisi model yang digunakan dalam penelitian, sebagaimana dalam penelitian Sofilda, et al Z. (2015) menggunakan pertumbuhan pendapatan perkapita sebagai variabel antara yang mempengaruhi Indeks Pembangunan Manusia di Indonesia. Sementara Edeme, (2014) lebih rinci menggunakan variabel pengeluaran pemerinatah untuk pembangunan infrastruktur pertanian, pembanguna pedesaan, energy, dan sanitasi terhadap Pembangunan Manusia di Nigeria. Artikel ini mengulas hasil penelitian terkait efektifitas 
belanja modal pemerintah dalam meningkatkan indeks pembangunan manusia di Kabupaten/Kota Provinsi Sulawesi Selatan.

\section{TINJAUAN TEORITIK / LITERATURE REVIEW}

Lembaga United Nations Development Programme (UNDP) telah mempublikasikan laporan pembangunan sumber daya manusia dalam ukuran kuantitatif yang disebut Human Development Indeks (HDI). Meskipun HDI merupakan alat ukur pembangunan SDM yang dirumuskan secara konstan, diakui tidak akan pernah menangkap gambaran pembangunan SDM secara sempurna.

Adapun indikator yang dipilih untuk mengukur dimensi HDI adalah sebagai berikut: Pertama, Longevity, diukur dengan variabel harapan hidup saat lahir atau life expectancy of birth dan angka kematian bayi per seribu penduduk atau (infant mortality rate). Kedua, Educational Achievement, diukur dengan dua indikator, yakni melek huruf penduduk usia 15 tahun ke atas (adult literacy rate) dan tahun rata-rata bersekolah bagi penduduk 25 ke atas (the mean years of schooling). Ketiga, Access to resource, dapat diukur secara makro melalui PDB rill perkapita dengan terminologi purchasing power parity dalam dolar AS dan dapat dilengkapi dengan tingkatan angkatan kerja (UNDP, Human Development Report 1993: 105-106).

Dari penjelasan tersebut dapat disimpulkan bahwa komponen-komponen yang mempengaruhi IPM antara lain; Indeks Pendidikan, Indeks Harapan hidup, dan Indeks Hidup Layak. Penghitungan Indeks Pendidikan (IP) mencakup dua indikator yaitu angka melek huruf (LIT) dan rata-rata lama sekolah (MYS). Populasi yang digunakan adalah penduduk berumur 15 tahun ke atas karena pada kenyataannya penduduk usia tersebut sudah ada yang berhenti sekolah. Batasan ini diperlukan agar angkanya lebih mencerminkan kondisi sebenarnya mengingat penduduk yang berusia kurang dari 15 tahun masih dalam proses sekolah atau akan sekolah sehingga belum pantas untuk rata-rata lama sekolahnya. Kedua indikator pendidikan ini dimunculkan dengan harapan dapat mencerminkan tingkat pengetahuan (cerminan angka LIT), dimana LIT merupakan proporsi penduduk yang memiliki kemampuan baca tulis dalam suatu kelompok penduduk secara keseluruhan. Sedangkan cerminan angka MYS merupakan gambaran terhadap keterampilan yang dimiliki penduduk. 
Indeks Harapan Hidup menunjukkan jumlah tahun hidup yang diharapkan dapat dinikmati penduduk suatu wilayah. Dengan memasukkan informasi mengenai angka kelahiran dan kematian per tahun, variabel tersebut diharapkan akan mencerminkan ratarata lama hidup sekaligus hidup sehat masyarakat. Sehubungan dengan sulitnya mendapatkan informasi orang yang meninggal pada kurun waktu tertentu, maka untuk menghitung angka harapan hidup digunakan metode tidak langsung. Data dasar yang dibutuhkan dalam metode ini adalah rata-rata anak lahir hidup dan rata-rata anak masih hidup dari wanita pernah kawin. Secara singkat, proses penghitungan angka harapan hidup ini disediakan oleh program Mortpak. Untuk mendapatkan Indeks Harapan Hidup dengan cara menstandartkan angka harapan hidup terhadap nilai maksimum dan minimumnya.

Untuk mengukur dimensi standar hidup layak (daya beli), UNDP mengunakan indikator yang dikenal dengan real per kapita GDP adjusted. Untuk perhitungan IPM sub nasional (provinsi atau kabupaten/kota) tidak memakai PDRB per kapita karena PDRB per kapita hanya mengukur produksi suatu wilayah dan tidak mencerminkan daya beli riil masyarakat yang merupakan konsentrasi IPM. Untuk mengukur daya beli penduduk antar provinsi di Indonesia, BPS menggunakan data rata-rata konsumsi 27 komoditi terpilih dari Survei Sosial Ekonomi Nasional (SUSENAS) yang dianggap paling dominan dikonsumsi oleh masyarakat Indonesia dan telah distandarkan agar bisa dibandingkan antar daerah dan antar waktu yang disesuaikan dengan indeks PPP (Purchasing Power Parity).

Lain halnya dengan Todaro (2006) yang mengungkapkan bahwa pembangunan manusia ada tiga komponen universal sebagai tujuan utama meliputi: Petama, Kecukupan, yaitu merupakan kebutuhan dasar manusia secara fisik. Kebutuhan dasar adalah kebutuhan yang apabila tidak dipenuhi akan menghentikan kehidupan seseorang, meliputi pangan, sandang, papan, kesehatan dan keamanan. Jika satu saja tidak terpenuhi akan menyebabkan keterbelakangan absolut.

Kedua, Jati Diri, yaitu merupakan komponen dari kehidupan yang serba lebih baik adalah adanya dorongan dari diri sendiri untuk maju, untuk menghargai diri sendiri, untuk merasa diri pantas dan layak mengejar sesuatu, dan seterusnya. Semuanya itu terangkum dalam self esteem (jati diri). Ketiga, Kebebasan dari Sikap Menghamba, yaitu merupakan kemampuan untuk memiliki nilai universal yang tercantum dalam pembangunan manusia adalah kemerdekaan manusia. Kemerdekaan dan kebebasan di sini diartikan sebagai kemampuan berdiri tegak sehingga tidak diperbudak oleh pengejaran dari aspek-aspek 
materil dalam kehidupan. Dengan adanya kebebasan kita tidak hanya semata-mata dipilih tapi kitalah yang memilih.

Dalam indeks pembangunan manusia terdapat tiga komposisi indikator yang digunakan untuk mengukur besar indeks pembangunan manusia suatu negara, yaitu ; Pertama, Tingkat kesehatan diukur harapan hidup saat lahir (tingkat kematian bayi). Kedua, Tingkat pendidikan diukur dengan angka melek huruf (dengan bobot dua per tiga) dan ratarata lama sekolah (dengan bobot sepertiga). Ketiga, Standar kehidupan diukur dengan tingkat pengeluaran perkapita per tahun. Rumus umum yang digunakan untuk menghitung Indeks Pembangunan Manusia adalah sebagai berikut:

$\mathrm{IPM}=1 / 3$ (Indeks X1 + Indeks X2 + Indeks X3)

Dimana:

$\mathrm{X} 1$ = Indeks harapan hidup

$\mathrm{X} 2$ = Indeks pendidikan

X3 = Indeks standar hidup layak

Dalam hal keterkaitan dengan belanja pemerintah, Rostow dan Musgrave cit Vildzah (2016) menghubungkan perkembangan pengeluaran pemerintah dengan tahap-tahap pembangunan ekonomi yaitu tahap awal, tahap menengah dan tahap lanjut. Perkembangan pengeluaran pemerintah oleh Adolf Wagner menjelaskan bahwa semakin meningkatnya pendapatan per kapita dalam suatu perekonomian maka secara relatif pengeluaran pemerintah akan meningkat. Sehingga kurva peningkatan pengeluaran pemerintah berbentuk eksponensial. Hukum Wagner yang terkenal yaitu "The Law of Expanding State Expenditure" dimana pengeluaran pemerintah terus meningkat disebabkan oleh peranan pemerintah yang semakin besar dalam mengurus segala aktivitas yang berhubungan dengan masyarakat, hukum, pendidikan, rekreasi dan kebudayaan.

\section{METODE PENELITIAN / METHODS}

Metode yang digunakan adalah metode eksplanatori. Pendekatan ini bertujuan untuk menguji suatu teori atau hipotesis guna memperkuat atau bahkan menolak teori atau hipotesis hasil penelitian yang sudah ada sebelumnya. Penelitian eksplanatori atau eksplanatif bertujuan untuk menjelaskan hubungan antara dua atau lebih gejala atau variabel (Leedy et al., 2005). 
Jenis data yang digunakan pada penelitian ini berupa data sekunder, dalam bentuk panel data (pooled data) yang menggabungkan data time series periode 2007-2016 dan data cross section Kabupaten/Kota Provinsi Sulawesi Selatan. Data-data yang dimaksud yaitu belanja pendidikan, belanja kesehatan dan belanja ekonomi seluruh Kabupaten/Kota Provinsi Sulawesi Selatan, serta data IPM Provinsi Sulawesi Selatan yang diperoleh dari data BPS yang dipublikasi secara online.

Teknik yang digunakan dengan persamaan exponential function dengan multiple regression, sebagai berikut;

$$
\text { IPM }_{t}=\beta_{0} \text { BPend }_{t}^{\beta 1} \text { BKes }_{t}{ }^{\beta 2} \text { BEKo }_{t}{ }^{\beta 3} \text { PEKo }_{t}{ }^{\beta 4} \mu_{t}
$$

Untuk mengestimasikan koefisien regresi, sesuai pendapat Feldstein (1988) dilakukan transformasi ke bentuk linear dengan menggunakan logaritma natural $(I n)$ parsial ke dalam model sehingga diperoleh persamaan sebagai berikut:

\begin{tabular}{|c|c|}
\hline Dimana: & \\
\hline IPM & : Indeks Pembangunan Manusia (Persen) \\
\hline$\beta 0$ & : Konstanta \\
\hline$\beta_{1}, \beta_{2}, \beta_{3}, \beta_{4}$ & : Koefisien Regresi \\
\hline BPend & : Belanja Pendidikan (Rupiah) \\
\hline BKes & : Belanja Kesehatan (Rupiah) \\
\hline BEko & : Belanja Ekonomi (Rupiah) \\
\hline Ln & : Logaritma Natural \\
\hline$t$ & : Time Series/cross section (tahun) \\
\hline 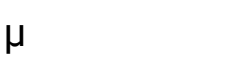 & : Error term \\
\hline
\end{tabular}

\section{HASIL DAN PEMBAHASAN / DISCUSSION}

Analisis regresi berganda digunakan untuk mengetahui arah hubungan antara variabel independen dan variabel dependen. Persamaan regresi dapat dilihat dari tabel hasil uji koefisien berdasarakan output SPSS terhadap ketiga variabel independen yaitu belanja modal pendidikan, belanja modal kesehatan, dan belanja modal ekonomi, terhadap variabel dependen yaitu indeks pembangunan manusia kabupaten/kota di Sulawesi Selatan selama periode pengamatan. 
Berdasarkan hasil analisis regresi maka dihasilkan persamaan regresi sebagai berikut:

Ln IPM $_{t}=4,429+0,045$ Ln BPend $+0,053$ Ln BKest $+0,023$ Ln BEko + 0,041 $\mu_{t}$

1) Nilai Koefisien

Nilai koefisien $\beta 0$ sebesar 4,429, angka tersebut menunjukkan bahwa jika Belanja Modal Pendidikan (X1), Belanja Modal Kesehatan (X2), Belanja Modal Ekonomi (X3) nilainya 0 atau konstan maka Indeks Pembanguan Manusia sebesar 4,429.

2) Belanja Modal Pendidikan

Variabel bebas belanja modal pendidikan (X1) mempunyai koefisien regresi $\beta 1$ sebesar 0,045 menunjukkan pengaruh belanja modal pendidikan yang bernilai positif $(+)$. Artinya apabila belanja modal pendidikan bertambah 1 satuan (Miliar Rupiah) maka akan menyebabkan peningkatan indeks pembangunan manusia sebesar 0,045, dengan asumsi belanja modal kesehatan (X2), belanja modal ekonomi (X3) dianggap konstan.

3) Belanja Modal Kesehatan

Variabel belanja modal kesehatan (X2) mempunyai koefisien regresi $\beta 2$ sebesar 0,053 menunjukkan pengaruh belanja modal kesehatan yang bernilai positif (+). Artinya apabila belanja modal kesehatan bertambah sebesar 1 satuan (Miliar Rupiah) maka akan menyebabkan peningkatan indeks pembangunan manusia sebesar 0,053 dengan asumsi belanja modal pendidikan (X1), belanja modal ekonomi (X3) dianggap konstan.

4) Belanja Modal Ekonomi

Variabel bebas belanja modal ekonomi (X3) mempunyai koefisien regresi $\beta 3$ sebesar 0,023 menunjukkan pengaruh belanja modal ekonomi yang bernilai negatif $(+)$. Artinya apabila belanja modal ekonomi bertambah sebesar 1 satuan (Miliar Rupiah) maka akan menyebabkan peningkatan indeks pembangunan manusia sebesar 0,023 dengan asumsi belanja modal pendidikan (X1), belanja modal kesehatan (X2) dianggap konstan. 
Berikut adalah tabel ringkasan hasil analisis linear berganda:

Tabel 1. Hasil Analisis Regresi

\begin{tabular}{lccc}
\hline Variabel Independen & B & t- Hit & Sign \\
\hline Belanja Modal Pendidikan $\left(\mathrm{X}_{1}\right)$ & 0,045 & 3,406 & 0,001 \\
Belanja Modal Kesehatan $\left(\mathrm{X}_{2}\right)$ & 0,053 & 4,027 & 0,000 \\
Belanja Modal Ekonomi $\left(\mathrm{X}_{3}\right)$ & 0,023 & 5,971 & 0,000 \\
\hline Konstanta & & & 4,429 \\
\hline F Hitung & & & 17,200 \\
\hline$R$ Square $\left(R^{2}\right)$ & & 0,511 \\
\hline Adjusted $\mathrm{R}^{2}$ & & 0,509 \\
\hline Sampel $(\mathrm{n})$ & & 240 \\
\hline
\end{tabular}

Sumber: Output data sekunder setelah diolah, Tahun 2018.

\section{a. Koefisien Determinasi ( $R$ Square)}

Koefisien determinasi digunakan untuk mengukur seberapa jauh kemampuan model dalam menerangkan variasi variabel dependen. Nilai koefisien determinasi antara 0 dan 1. Saat nilai koefisien mendekati satu, berarti kemampuan variabel-variabel independen menunjukkan hampir semua informasi yang dibutuhkan untuk memprediksi variasi variabel dependen.

Hasil dari perhitungan diperoleh nilai koefisien determinasi $R$ Square sebesar 0,511 , yang artinya bahwa $51,1 \%$ variasi perubahan indeks pembangunan manusia kabupaten/kota di Sulawesi Selatan dapat dijelaskan oleh variabel bebas yaitu Belanja Modal Pendidikan (X1), Belanja Modal Kesehatan (X2), Belanja Modal Ekonomi (X3) sedangkan sisanya sebesar $48,9 \%$ dipengaruhi oleh variabel-variabel lain yang tidak dimasukkan dalam model regresi.

\section{b. Uji Hipotesis}

\section{1) Uji t}

Uji t dilakukan untuk mengetahui pengaruh variabel independen belanja modal pendidikan (X1), belanja modal kesehatan (X2), belanja modal ekonomi (X3) secara parsial terhadap variabel dependen indeks pembangunan manusia kabupaten/kota di Sulawesi Selatan, dengan menganggap variabel lain konstan. Signifikansi tersebut dapat diestimasi dengan membandingkan antara nilai $t_{\text {tabel }}$ dengan $t_{\text {hitung }}$.

1. Pengaruh belanja modal pendidikan terhadap indeks pembangunan manusia kabupaten/kota di Sulawesi Selatan 
Berdasarkan Tabel 4. diperoleh nilai signifikansi untuk variabel belanja modal pendidikan adalah 0,001 dinyatakan lebih kecil dari taraf $a=0.05(0,001<0,05)$, dengan nilai $t_{\text {hitung }}=3,406$ dan dengan nilai $t_{\text {tabel }}=2,447$ sehingga $t_{\text {hitung }}>t_{\text {tabel }}(3,406>2,447)$. Dari hasil tersebut sehingga dapat disimpulkan bahwa variabel belanja modal pendidikan mempunyai pengaruh positif dan signifikan terhadap indeks pembangunan manusia kabupaten/kota di Sulawesi Selatan. Hal ini sesuai dengan hipotesis sebelumnya bahwa belanja modal pendidikan berpengaruh positif terhadap indeks pembangunan manusia kabupaten/kota di Sulawesi Selatan.

2. Pengaruh belanja modal kesehatan terhadap indeks pembangunan manusia kabupaten/kota di Sulawesi Selatan

Berdasarkan Tabel 4. diperoleh nilai signifikansi untuk variabel belanja modal pendidikan adalah 0,000 dinyatakan lebih kecil dari taraf $a=0.05(0,000<0,00)$, dengan nilai $t_{\text {hitung }}=4,027$ dan dengan nilai $t_{\text {tabel }}=2,447$ sehingga $t_{\text {hitung }}>t_{\text {tabel }}(4,027>2,447)$. Dari hasil tersebut sehingga dapat disimpulkan bahwa variabel belanja modal kesehatan mempunyai pengaruh positif dan signifikan terhadap indeks pembangunan manusia kabupaten/kota di Sulawesi Selatan. Hal ini sesuai dengan hipotesis sebelumnya bahwa belanja modal kesehatan berpengaruh positif terhadap indeks pembangunan manusia kabupaten/kota di Sulawesi Selatan.

3. Pengaruh belanja modal kesehatan terhadap indeks pembangunan manusia kabupaten/kota di Sulawesi Selatan

Berdasarkan Tabel 4. diperoleh nilai signifikansi untuk variabel belanja modal ekonomi adalah 0,000 dinyatakan lebih kecil dari taraf $a=0.05(0,000<0,00)$, dengan nilai $t_{\text {hitung }}=5,971$ dan dengan nilai $t_{\text {tabel }}=2,447$ sehingga $t_{\text {hitung }}>t_{\text {tabel }}(5,971>2,447)$. Dari hasil tersebut sehingga dapat disimpulkan bahwa variabel belanja modal ekonomi mempunyai pengaruh positif dan signifikan terhadap indeks pembangunan manusia kabupaten/kota di Sulawesi Selatan. Hal ini sesuai dengan hipotesis sebelumnya bahwa belanja modal ekonomi berpengaruh positif terhadap indeks pembangunan manusia kabupaten/kota di Sulawesi Selatan.

\section{2) Uji F}

Uji $\mathrm{F}$ dilakukan untuk mengetahui pengaruh semua variabel independen yang dimasukkan dalam model mempunyai pengaruh secara bersama-sama terhadap variabel dependennya. Uji $\mathrm{F}$ dilakukan dengan membandingkan $F_{\text {hitung }}$ dan $F_{\text {tabel. }}$ Jika nilai taraf 
signifikasi $F_{\text {hitung }}<\mathrm{a}=0.05$ juga dibuktikan dengan jika nilai $F_{\text {hitung }}>F_{\text {tabel }}$ Jika nilai signifikansi $F_{\text {hitung }}$ dibawah a $=0.05$ dan jika $F_{\text {hitung }}>F_{\text {tabel }}$ maka variabel independen dalam penelitian ini secara bersama-sama berpengaruh terhadap variabel dependen.

Hasil perhitungan uji $\mathrm{F}$ dapat dilihat pada Tabel 4. Dari hasil regresi pengaruh variabel belanja modal pendidikan (X1), belanja modal kesehatan (X2), belanja modal ekonomi (X3) secara parsial terhadap variabel dependen indeks pembangunan manusia kabupaten/kota di Sulawesi Selatan (Y), maka diperoleh nilai $F_{\text {hitung }}$ sebesar 17,200 dengan signifikansi sebesar 0.000 lebih kecil dari taraf signifikansi yang digunakan dalam penelitian ini yaitu $0.05(0.000<0.05)$. Hal ini menunjukkan bahwa ketiga variabel independen secara simultan atau bersama-sama berpengaruh signifikan terhadap variabel dependen.

\section{Implikasi Belanja Modal Pendidikan terhadap IPM Kabupaten/Kota di Sulawesi Selatan.}

Hasil penelitian menunjukkan bahwa belanja modal disektor pendidikan tahun berpengaruh signifikan positif terhadap IPM Kabupaten/Kota di Provinsi Sulawesi Selatan. Peningkatan alokasi belanja modal pada sektor pendidikan memberikan dampak positif terhadap upaya untuk meningkatkan indeks pembangunan manusia kabupaten/kota di provinsi Sulawesi Selatan. Dengan demikian sasaran belanja modal pada bidang pendidikan dihapakan dapat memacu harapan lama sekolah, dan rata-rata lama sekolah mengalami peningkatan di semua kabupaten/kota di provinsi Sulawesi Selatan.

Hasil penelitian ini sejalan dengan penelitian yang dilakukan oleh Nur Isa Pratowo (2013), Mahulauw, Abdul Kadir, dkk, (2017), Paddu dkk (2014), Kahang, dkk, (2017), dan Irawan (2014). Dengan menyatakan hasil bahwa alokasi belanja pemerintah disektor pendidikan khususnya belanja modal berpengaruh signifikan terhadap indeks pembangunan manusia.

Pengeluaran pembangunan pada sektor pembangunan dapat dialokasikan untuk penyediaan infrastruktur pendidikan dan menyelenggarakan pelayanan pendidikan kepada seluruh penduduk Indonesia secara merata. Anggaran pendidikan sebesar 20 APBN persen merupakan wujud realisasi pemerintah untuk meningkatkan pendidikan. Pemerintah menempatkan pendidikan sebagai faktor penting dalam menunjang pembangunan nasional. Hal tersebut terlihat dari besarnya pengeluaran pemerintah untuk sektor pendidikan. Pemerintah menyediakan anggaran minimal $20 \%$ dari APBN untuk bidang pendidikan. Hal tersebut tercantum dalam UndangUndang No. 20 Tahun 2003 Tentang Sistem Pendidikan Nasional Pasal 49 mengamanatkan bahwa dana pendidikan selain gaji pendidik dan biaya 
pendidikan kedinasan dialokasikan minimal 20\% dari Anggaran Pendapatan dan Belanja Negara (APBN) pada sektor pendidikan dan minimal 20\% dari Anggaran Pendapatan dan Belanja Daerah (APBD), (Kahang, dkk, 2017).

Konsekuensi dari tinggi dan rendahnya pengeluaran pada sektor pendidikan adalah Indeks Pendidikan yang diperoleh di masing-masing daerah. Tren alokasi balanja pendidikan pada kabupaten/kota di provinsi Sulawesi selatan terus mengalami peningkatan. Hal ini sejalan dengan program peningkatan kualitas infrastruktur pendidikan dalam upaya mendongkrak kualitas pendidikan di seluruh wilayah Sulawesi Selatan. Sejalan dengan hal tersebut seluruh wilayah kabupaten kota juga telah menerapkan pendidikan gratis pada tingkatan pendidikan wajib 12 tahun, sebagai upaya untuk mengangkat kualitas manusia di Sulawesi Selatan, dan tentunya berdampak positif terhadap Indeks pembangunan manusia di seluruh wilayah ini.

Pendidikan memperluas peluang seseorang. Pendidikan meningkatkan kreativitas dan imajinasi. Sebagai nilai tambah, pendidikan juga akan memperluas pilihan-pilihan lain. Manusia yang berpendidikan akan lebih memperhatikan tingkat kesehatan agar dapat hidup lebih lama. Tidak hanya itu, manusia yang berpendidikan juga akan berpeluang besar mendapatkan pekerjaan dan pendapatan yang lebih layak. Oleh karena itu, pendidikan menjadi penting sebagai sarana untuk meningkatkan kualitas manusia agar dapat memperluas peluang mereka (BPS, 2014).

Negara-negara termiskin di dunia ditandai dengan teramat rendahnya pengeluaran biaya untuk kesehatan dibanding dengan standar negara-negara berpendapatan tinggi. Walaupun seandainya negara-negara miskin tersebut mengalokasikan sumber daya dalam negeri lebih banyak untuk kesehatan hal ini tidak akan memecahkan masalah mendasar: negara-negara miskin tidak memiliki sumber daya biaya yang dibutuhkan untuk memenuhi kebutuhan pelayanan kesehatan dasar bagi masyarakatnya. Dengan perkiraan US\$30 - 40 per kapita untuk pelayanan esensial, jumlah ini akan menyerap sekitar $10 \%$ dari GNP dari negara miskin tersebut, jauh dari sumber daya dalam negeri yang dapat dimobilisasikan (Sujudi, 2003).

Dengan besarnya jumlah belanja pendidikan melalui adanya berbagai program bantuan dari pemerintah sebagian besar penduduk di Provinsi Sulawesi Selatan dapat mengenyam pendidikan formal. Dilihat pada angka melek huruf yang tertinggi adalah Kota 
Makassar. Sementara angka melek huruf yang rendah masih ada didaerah Kabupaten Jeneponto, Bantaeng dan Gowa.

Meskipun demikian angka melek huruf tidak lagi dijadikan sasaran dalam upaya peningktan indeks pendidikan di indonesi, pandangan ini telah dianggap kurang relevan dengan kondisi saat ini. Oleh karena itu Badan pusat Statistik pada tahun 2014 merilis metode baru dalam mengukur indeks pembangunan manusia, dengan menggunakan Ratarata lama sekolah, dan Harapan lama sekolah.

Pada dasarnya, perubahan metodologi penghitungan IPM didasarkan pada alasan yang cukup rasional. Suatu indeks komposit harus mampu mengukur apa yang diukur. Dengan pemilihan metode dan variabel yang tepat, indeks yang dihasilkan akan cukup relevan. Namun, alasan utama yang dijadikan dasar perubahan metodologi penghitungan IPM setidaknya ada dua hal mendasar (BPS, 2014).

Pertama, beberapa indikator sudah tidak tepat untuk digunakan dalam penghitungan IPM. Angka Melek Huruf (AMH) sudah tidak relevan dalam mengukur pendidikan secara utuh karena tidak dapat menggambarkan kualitas pendidikan. Sebelum penghitungan metode baru digunakan, AMH di sebagian besar daerah sudah tinggi, sehingga tidak dapat membedakan tingkat pendidikan antar wilayah dengan baik. Dalam konsep pembentukan indeks komposit, variabel yang tidak sensitif membedakan akan menyebakan indikator komposit menjadi tidak relevan. Oleh karena itu, indikator $\mathrm{AMH}$ dianggap sudah tidak relevan sebagai komponen dalam penghitungan IPM. Kedua, penggunaan rumus rata-rata aritmatik dalam penghitungan IPM menggambarkan bahwa capaian yang rendah di suatu dimensi dapat ditutupi oleh capaian tinggi dari dimensi lain. Pada dasarnya, konsep yang diusung dalam pembangunan manusia adalah pemerataan pembangunan dan sangat anti terhadap ketimpangan pembangunan. Rata-rata aritmatik memungkinkan adanya transfer capaian dari dimensi dengan capaian tinggi ke dimensi dengan capaian rendah (BPS, 2014).

\section{Implikasi Belanja Modal Kesehtan terhadap IPM Kabupaten/Kota di Sulawesi Selatan.}

Hasil penelitian ini menunjukkan bahwa belanja modal disektor Kesehatan tahun berpengaruh signifikan positif terhadap IPM Kabupaten/Kota di Provinsi Sulawesi Selatan. Peningkatan alokasi belanja modal pada sektor kesehatan memberikan dampak positif terhadap upaya untuk meningkatkan inndeks pembangunan manusia kabupaten/kota di provinsi Sulawesi Selatan. 
Hasil Penelitian ini tidak konsisten dengan penelitian yang dilakukan Oleh Kahang, dkk 2017, yang menyatakan bahwa Pengeluaran Pemerintah Sektor Kesehatan berpengaruh negatif dan tidak signifikan terhadap Indeks Pembangunan Manusia di Kabupaten Kutai Timur. Sedangkan penelitian yang dilakukan oleh Mahulauw, dkk, 2017, menunjukan hasil bahwa Pengeluaran Pemerintah Sektor Kesehatan berpengaruh positif dan signifikan terhadap Indeks Pembangunan Manusia Kabupaten/Kota di Provinsi Maluku.

Hidup lebih lama merupakan dambaan setiap orang. Untuk dapat berumur panjang, diperlukan kesehatan yang lebih baik. Pembangunan manusia memperluas pilihan-pilihan manusia dengan mensyaratkan berumur panjang. Proksi umur panjang dan sehat yang digunakan dalam pembangunan manusia adalah indikator angka harapan hidup saat lahir. Indikator ini menjadi salah satu indikator gambaran kesehatan masyarakat.

Hasil Penelitian Saha Cit Mahulauw, dkk (2017), mengenai implikasi tingkat kesehatan terhadap pertumbuhan produktivitas dan pertumbuhan ekonomi mengemukakan bahwa peningkatan pengeluaran kesehatan dapat mengurangi angka kematian dan meningkatkan harapan hidup. Saluran fiskal melalui belanja bidang kesehatan secara efektif berdampak terhadap pembangunan manusia. Dengan pengeluaran bidang kesehatan, orang lebih sehat dapat hidup lebih lama dan juga dapat bekerja lebih baik dengan tingkat produksi yang lebih tinggi. Tingkat kesehatan yang lebih baik juga menunjang seseorang dapat mengakses tingkat pendidikan yang lebih tinggi.

Selama kurun waktu 2010 hingga 2014, angka harapan hidup Indonesia terus meningkat. Artinya, harapan seorang bayi yang baru lahir untuk dapat hidup lebih lama menjadi semakin tinggi. Saat ini, angka harapanhidup saat lahir di Indonesia telah mencapai 70,59 tahun. Selama empat tahun, angka harapan hidup saat lahir di Indonesia tumbuh 0,28 persen per tahun.

Peningkatan belanja modal di sektor kesehatan setiap tahunnya menjadikan bukti bahwa akses fasilitas kesehatan semakin terjangkau. Namun, akses tersebut masih terasa sulit bagi kelompok masyarakat berpendapatan rendah. Semakin rendah pendapatan seseorang nampaknya akan semakin rendah pula akses persalinan medis bagi mereka. Inilah salah satu tantangan yang perlu dikaji oleh pemerintah. Setiap tahunnya program kesehatan gratis selalu digalakkan oleh pemerintah Sulawesi Selatan. Anggaran pun yang digulirkan pemerintah setempat terus meningkat, terjangkaunya pelayanan kesehatan terbaik untuk masyarakatnya (BPS, 2015). 


\section{Implikasi Belanja Modal Ekonomi terhadap IPM Kabupaten/Kota di Sulawesi}

\section{Selatan.}

Hasil penelitian ini menunjukkan bahwa belanja modal disektor Ekonomi tahun berpengaruh signifikan positif terhadap IPM Kabupaten/Kota di Provinsi Sulawesi Selatan. Peningkatan alokasi belanja modal pada sektor ekonomi memberikan dampak positif terhadap upaya untuk meningkatkan inndeks pembangunan manusia kabupaten/kota di provinsi Sulawesi Selatan. Anggaran bidang ekonomi digunakan untuk menyasar pembangunan infrastruktur yang dapat memperlancar aksesibititas warga dalam interaksi ekonomi antar wilayah, dan mengurangi kesenjangan pembangunan antar kabupaten/kota di Sulawesi Selatan.

Penelitian ini sejalan dengan penelitian yang dilakukan oleh Mahulauw, dkk (2017), menunjukan hasil bahwa Pengeluaran Pemerintah Sektor pembangunan infrastruktur berpengaruh positif dan signifikan terhadap Indeks Pembangunan Manusia Kabupaten/Kota di Provinsi Maluku.

Sapkota Cit Mahulauw, dkk (2017) menemukan bahwa aksesbilitas infrastruktur yang lebih baik berkat alokasi anggaran yang lebih tinggi dapat mereduksi tingkat kemiskinan secara signifikan. Sapkota menemukan variabel infrastruktur seperti akses listrik dan air berdampak positif dan signifikan terhadap IPM. Ketersediaan aksesbilitas infrastruktur seperti listrik dapat meningkatkan pendapatan karena usaha masyarakat dan segala lini aktivitas lebih produktif, sehingga daya beli menjadi meningkat dan otomatis meningkatkan indeks IPM

Selama tahun 2010 hingga 2014, terjadi kemajuan pembangunan manusia di kawasan barat dan timur. Meski dari sisi capaian kawasan barat lebih unggul, penurunan kesenjangan pembangunan manusia di kawasan ini cenderung lebih lambat. Kesenjangan IPM tertinggi dan terendah di kawasan barat hanya sedikit berkurang dari 28,23 di tahun 2010 menjadi 27,05 pada tahun 2014. Sebaliknya, penurunan kesenjangan pembangunan manusia di kawasan timur cenderung lebih cepat. Pada tahun 2010, perbedaan capaian IPM tertinggi dan terendah di kawasan timur mencapai 58,51. Tahun 2014, perbedaan tersebut berkurang menjadi 55,92.

Upaya pemerataan pencapaian pembangunan antar kawasan sebetulnya sudah diupayakan pemerintah dalam pelaksanaan Masterplan Percepatan dan Perluasan Pembangunan Ekonomi Indonesia (MP3EI) yang tujuannya adalah mengembangkan potensi ekonomi wilayah di 6 (enam) Koridor Ekonomi Indonesia, yaitu: Koridor Ekonomi Sumatera, 
Koridor Ekonomi Jawa, Koridor Ekonomi Kalimantan, Koridor Ekonomi Sulawesi, Koridor Ekonomi Bali-Nusa Tenggara, dan Koridor Ekonomi Papua-Kepulauan Maluku; dan memperkuat kemampuan SDM untuk mendukung pengembangan program utama di setiap koridor ekonomi (Kemenko Bidang Perekonomian, 2011). Peningkatan kualitas SDM merupakan salah satu upaya untuk meningkatkan pembangunan manusia (BPS, 2014).

Dukungan belanja ekonomi khususnya belanja modal infrastruktur memberikan dampak yang besar terhadap kemajuan ekonomi di daerah. Dengan demikian akan meningkatkan ouput perkapita di daerah tersebut. Peningkatan output perkapita akan terus merangsang pertumbuhan ekonomi dan penyerapan tenaga kerja.

\section{KESIMPULAN / CONCLUSION}

Belanja modal pendidikan, belanja Kesehatan, dan belanja ekonomi memberikan implikasi signifikan positif terhadap IPM kabupaten/kota di Provinsi Sulawesi Selatan. Diperlukan alokasi belanja pemerintah di sektor pendidikan yang lebih berorientasi pada pemerataan fasilitas pendidikan yang dapat menunjang kualitas pendidikan khususnya di daerah-daerah yang tingkat IPM nya tergolong rendah dibandingkan daerah yang lainya. Sementara disektor kesehatan Diperlukan pula program-program innovatif di bidang kesehatan seperti pelayanan kesehatan 24 jam pada daerah-daerah terpencil, pemberlakuan pelayanan yang setara antar golongan masyarakat, serta peningkatan fasilitas pelayanan kesehatan yang mempuni di masing-masing daerah. Anggaran bidang ekonomi digunakan untuk menyasar pembangunan infrastruktur yang dapat memperlancar aksesibititas warga dalam interaksi ekonomi antar wilayah, dan mengurangi kesenjangan pembangunan antar kabupaten/kota di Sulawesi Selatan.

\section{DAFTAR PUSTAKA/ REFERENCES}

Ayu Bhakti, Nadia Ayu, Istiqomah Istiqomah, and Suprapto Suprapto, (2018). "Analisis Faktor-faktor yang Mempengaruhi Indeks Pembangunan Manusia di Indonesia Periode 2008-2012." EKUITAS: Jurnal Ekonomi dan Keuangan 18.4: 542-469.

Arifin, Mochammad Yuli. 2015. Pengaruh Belanja Pemerintah Sektor Kesehatan, Belanja Pemerintah Sektor Pendidikan dan Pertumbuhan Ekonomi Terhadap Indeks Pembangunan Manusia Jawa Timur 2006-2013. Jurnal: Economia, Volume 3, Nomor 1, Edisi April 2015. Jurusan Ilmu Ekonomi dan Studi Pembangunan, Fakultas Ekonomi, Universitas Jember (UNEJ). 
Edeme, R. K. (2014). Analyzing the effects of sectoral public spending on human development in nigeria: evidence from panel data. IOSR Journal of Humanities and Social Science (IOSR-JHSS), 19(9), 1-13.

Guritno, Mangkoesoebroto. 2012. Ekonomi Publik. Yogyakarta: BPFE.

Irawan, Hakim. 2014. Faktor-Faktor yang mempengaruhi IPM di Indonesia Periode 20062012. Skripsi: Jurusan Ekonomi Pembangunan, Fakultas Ekonomi dan Bisnis, Universitas Hasanuddin Makassar.

Jember, I. Made. "Pengaruh Pertumbuhan Ekonomi, Kemiskinan, Dan Belanja Daerah Terhadap Indeks Pembangunan Manusia Di Kabupaten Kota Provinsi Bali Periode 2005-2013."

Jhingan, ML. 2014. Ekonomi Pembangunan dan Perencanaan. Penerjemah: D.Guritno. Jakarta: PT Raja Grafindo Persada.

Jusaeman, Ahyadi. 2014. Analisis Faktor-Faktor Yang Mempengaruhi Peningkatan Mutu Modal Manusia di Kabupaten Soppeng. Skripsi: Jurusan Ilmu Ekonomi, Fakultas Ekonomi dan Bisnis, Univeritas Hasanuddin Makassar.

Kahang, M., \& budi Suharto, R. (2017, January). Pengaruh pengeluaran pemerintah sektor pendidikan dan kesehatan terhadap indkes pembangunan manusia di kabupaten kutai timur. In Forum Ekonomi (Vol. 18, No. 2, pp. 130-140).

Latuconsina, Zulfikar Mohamad Yamin. "Analisis Faktor-faktor yang Mempengaruhi Indeks Pembangunan Manusia Kabupaten Malang Berbasis Pendekatan Perwilayahan dan Regresi Panel." Journal of Regional and Rural Development Planning 1.2 (2017): 202216.

Leedy, Paul D., and Jeanne Ellis Ormrod, (2005). Practical Research. Pearson Custom, Mahulauw, Abdul Kadir, Dwi Budi Santosa, and Putu Mahardika, (2017). "Pengaruh Pengeluaran Kesehatan dan Pendidikan Serta Infrastruktur terhadap Indeks Pembangunan Manusia di Provinsi Maluku." Jurnal Ekonomi Pembangunan 14.2: 122148.

Prasetyo, Bambang. 2016. Metode Penelitian Kuantitatif. Jakarta: Rajawali Pers.

Pratowo, Nur Isa. "Analisis faktor-faktor yang berpengaruh terhadap Indeks Pembangunan Manusia." Jurnal Studi Ekonomi Indonesia (2013).

Sapkota, J. B. (2015). Infrastructure Access and Human Development: Cross-Country Evidence and Post-2015 Development Strategies. Journal of Globalization Studies.

Setiawan, Muhammad Bhakti, and Abdul Hakim. "Indeks pembangunan manusia Indonesia." Jurnal Economia 9.1 (2013): 18-26.

Shihab, Quraish. 1994. Membumikan Al Quran. Bandung: Mizan. 


\section{Jurnallaceses

Sujudi, Achmad. (2003). Investasi kesehatan untuk pembangunan ekonomi. Departemen Kesehatan RI.

Sofilda, E., \& Hamzah, M. Z. (2015). Government Spending Contributions on per Capita Income and its Effect toward the Human Development Index (Comparative Study between Western Indonesia and Central \& East Indonesia). Journal of Social and Development Sciences, 6(3), 43-49. https://doi.org/10.22610/jsds.v6i3.851

Suyuthi, Jalaluddin al. 2003. Al Durru Al Mantsur Fi Tafsir Bi Al Ma'Tsur.

Suryani, 2015 .Metode Riset Kuantitatif (Teori dan Aplikasi Pada Penelitian Ekonomi). Jakarta: Kencana.

Todaro, P Michael. 2011. Pembangunan Ekonomi jilid 1. Jakarta: Erlangga.

Wahyudin, Andi. 2015. Pengeluaran Publik dan Pembangunan Manusia di Sulawesi Selatan. Jurnal: Economia, Volume 2, Nomor 1 Edisi Mei 2015. Jurusan Ekonomi Pembangunan, Fakultas Ekonomi dan Bisnis, Universitas Hasanuddin Makassar.

Winarti, Astri. 2014. Analisis Pengaruh Belanja Pemerintah Bidang Kesehatan, Kemiskinan dan PDB Terhadap Indeks Pembangunan Manusia di Indonesia Periode 1992-2012. Skripsi: Jurusan Ilmu Ekonomi, Fakultas Ekonomi dan Bisnis, Universitas Diponegoro Semarang. 